\title{
Chevron Osteotomy with Herbert Screw Fixation for Treatment of Hallux Valgus Deformity Results
}

\author{
Halluks valgus cerrahisinde Herbert vidası ile yapılan Chevron osteotomisi \\ sonuçlarının değerlendirilmesi
}

\section{Tuluhan Yunus EMRE}

Orthopaedia and

Traumatology Department, Acıbadem Hospital, Istanbul, Turkey

\section{Yazışma Adresi:}

Tuluhan Yunus Emre

Address: Memorial Hizmet Hospital, Istanbul, Turkey

Telephone: 00905333077008

Fax Number: 00902124086641 drtuluhan@yahoo.com

\section{Öz}

Giriş: Halluks valgus 1.parmağın abduktor ve adduktor kaslarında gelişen dengesizlik sonucu meydana gelen ağrılı bir deformitedir. Chevron osteotomisi hafif ve orta şiddette seyreden halluks valgus deformitelerinin cerrahi tedavisinde etkili bir yöntemdir. Gereç ve Yöntem: Ortopedi ve Travmatoloji kliniğine başvuran, hafif ve orta şiddetli ağrılı halluks valgus deformitesi olan 33 genç hasta çalışmaya dahil edildi. Herbert vidası kullanılarak distal chevron osteotomi uygulanan hastalar ortalama 18 ay (6-30 ay) takip edildi. Hastaların değerlendirilmesinde preoperatif ve postoperatif 12. ayda American Orthopedic Foot and Ankle Society's (AOFAS) halluks-metatarsofalangeal-interfalangeal skalası kullanıldı. Sonuçlar:Preoperatif ve postoperatif ortalama halluks valgus açıları (HVA) sırasıyla $28.93^{\circ} \pm 6.66^{\circ}$ ve 9.48 ${ }^{\circ} \pm 3.21^{\circ}$ olarak ölçüldü. HVA arasındaki fark istatistiksel olarak anlamlı bulundu $(p=0.0001)$. Intermetatarsal açının (IMA) ise preoperatif dönemde ortalama $11.51^{\circ}$ \pm 2.41 'den postoperatif dönemde ortalama $7.53^{\circ} \pm 2.10^{\circ}$ 'ye düştüğü saptanmıştır ( $p$ $=0.0001$ ). Metatarsofalanjial dorsifleksiyon derecesinde $52.48^{\circ} \pm 9.71^{\circ}$ 'den 61.90 ${ }^{\circ} \pm 10.47^{\circ}$ 'ye yükselme gözlenmiştir $(p=0.0001)$. Plantar fleksiyon skorlarında ise anlamlı yükselme saptanmıştır $(p=0.0001)$. Preoperatif AOFAS skoru ortalaması 43,77 \pm 14.14 iken postoperatif dönemde ortalama $85.38 \pm 14.34$ olarak saptanmıştır ( $p=0.0001$ ). Tartışma: Halluks valgus cerrahisinde Herbert vidası ile yapılan Chevron osteotomisi ile kalıcı rotasyonel ve translasyonel stabilite sağlanabilmektedir.

Anahtar Kelimeler: Halluks valgus, Chevron osteotomy, Herbert vidası

\begin{abstract}
Objective: Hallux valgus is a painful deformity caused by an imbalance in the abductor and adductor muscle mechanism of the big toe. Chevron osteotomy is one of the effective surgical treatment methods for mild and moderate hallux valgus deformity. Materials and Methods: Thirty-three young patients who had mild to moderate hallux valgus deformity were admitted to Orthopedics and Traumatology inpatient clinic. Distal chevron osteotomy with Herbert screw fixation was applied with a mean follow-up of 18 (6-30 months). The American Orthopedic Foot and Ankle Society's (AOFAS) hallux-metatarsophalangeal-interphalangeal scale was used in preoperative physical assessment and at the 12 month postoperative assessment. Results: This results showed a significant decrease in the hallux valgus angle (HVA) from $28.93^{\circ} \pm 6.66^{\circ}$ preoperatively to $9.48^{\circ} \pm 3.21^{\circ}$ postoperatively $(p=0.0001)$. The intermetatarsal angle (IMA) also decreased from $11.51^{\circ} \pm 2.41^{\circ}$ preoperatively to $7.53^{\circ} \pm 2.10^{\circ}$ postoperatively $(p=0.0001)$. The degree of dorsiflexion of the first metatarsophalangeal joint significantly increased from $52.48^{\circ} \pm 9.71^{\circ}$ preoperatively to $61.90^{\circ} \pm 10.47^{\circ}$ postoperatively $(p=0.0001)$. Plantar flexion scores significantly increased from $20.36^{\circ} \pm 4.57^{\circ}$ preoperatively to $24.71^{\circ} \pm 5.18^{\circ}$ postoperatively $(p$ $=0.0001)$. The AOFAS score was $43.77^{\circ} \pm 14.14^{\circ}$ preoperatively, climbing to
\end{abstract}


$85.38^{\circ} \pm 14.34^{\circ}$ in the postoperative period $(p=0.0001)$. Conclusion: Although the chevron osteotomy has inherent stability, displacement can occur if the toe is traumatized in the early postoperative period. Herbert screw fixation in hallux valgus surgery provides strong and permanent rotational and translational stability which is correlated with satisfactory surgical outcomes.

Keywords: Hallux valgus, Chevron osteotomy, Herbert screw

\section{Introduction}

Hallux valgus, commonly known as a bunion, is a painful deformity of the first metatarsus and occurs due to an imbalance in the abductor and adductor muscle mechanism of the big toe. It is defined as a subluxation of the first metatarsal joint, with a medial deviation of the first metatarsus. It more commonly affects women. Podiatric surgeons are interested in advances in hallux valgus surgery due to its high occurrence (1-3).

A wide range of surgical techniques are available for the treatment of hallux valgus, including proximal, shaft, and distal osteotomies, depending upon the severity of the condition. Since 1976, chevron osteotomy has been one of the most effective surgical treatments of mild to moderate hallux valgus deformity (3-5). However, a more rigid, severe hallux valgus correction needs strong rotational and translational stability. The osteotomy stabilization technique is correlated with surgical success and varies among surgeons (1-4, 6-11). In the beginning, surgeons did not use any fixation technique, so complication rates were high and non-rigid stabilization was identified as the cause of many complications, thereupon fixation techniques with plates, bioabsorbable pins, Herbert screws and Kirschner wires were introduced $(2,6-10)$.

In order to achieve a high level of patient satisfaction, the best surgical treatment of a hallux deformity was established as a correction of the intermetatarsal angle (IMA) and hallux valgus angle (HVA). Despite a high clinical efficacy with these fixation implants, implant loosening, painful irritations of the soft tissue, and foreign body reactions are still reported. Furthermore, nonunion, malunion, delayed union, recurrence, osteomyelitis, hallux varus, excessive shortening of the first metatarsal, avascular necrosis of the metatarsal head, infection, and residual pain are the most common complications of hallux valgus surgery (6-10).

In this study, it is investigated whether distal chevron osteotomy with Herbert screw fixation would work better for rigid stability and rapid bone healing, while avoiding inflammatory sequelae due to the implant. The primary objective was to evaluate the patients' clinical recovery following hallux valgus surgery while the secondary objective was to show the bone healing with optimal correction amount.

The hypothesis is that distal chevron osteotomy with Herbert screw fixation has optimal stabilization which provides rapid bone healing with low complication rates in hallux valgus surgery as it serves ease of application by minimizing errors due to surgery.

\section{Patients and Methods}

After obtaining permission from local Ethical comitee and informed consent from from each patient, Thirty-three young patients (for a total of 34 feet) admitted to the Orthopedics and Traumatology inpatient clinic from October 1, 2012October 1, 2014 were included in the study. Patients with a mild (flexible metatarsophalangeal deformity with an IMA less than $13^{\circ}, \mathrm{HVA}$ equal or more than $20^{\circ}$, less than $25^{\circ}$ ) to moderate (rigid deformity with an IMA equal or more than $13^{\circ}$, HVA of $26-40^{\circ}$ ) hallux valgus deformity underwent distal chevron osteotomy of the first metatarsal with Herbert screw fixation. Each patient was followed-up for an average of 18 months and the study was completed by October 1 , 2014. While many reports have stated that hallux valgus is mostly observed in females, in this study, all of the patients were male recruits which differantiates the study from the literature. Patients with a history of steroid use, a history of prior surgeries on the same foot, and patients who had chronic conditions that could affect bone healing were excluded from the study.

Twenty six patients were male and seven were female. The mean age was $29.11 \pm 9.7$ years (21-53 years). The hallux valgus deformity was located on the right foot in 16 patients $(47 \%)$ and on the left foot in 18 patients (53\%). Demographic information was recorded for each patient. Anamnesis, physical examination of the first metatarsophalangeal joint including range of motion, and pain level were evaluated simultaneously. Postoperatively, patients were examined at 3,6 , and 12 weeks, and at 6,12 , and 18 months.

The surgical procedure and patient follow-up was performed by the same surgeon. All surgical interventions were performed under spinal anesthesia with patient in the supine position. First generation cephalosporin $(1 \mathrm{~g}$ cefazolin) was applied 1 hour preoperatively and a limb tourniquet was used. After making a dorsomedial skin and capsular $\mathrm{L}$ incision of the first metatarsal, bunion excision was performed. 
Following the lateral conjoint tendon release (Fig. 1), a distal metatarsal v-shaped $\left(>60^{\circ}\right)$ chevron osteotomy was performed (Fig. 2). The capital fragment was displaced laterally until the coronal/sagittal plane was sufficient for correct first ray alignment. After correction, we used a $\mathrm{K}$-wire from the dorsum of the distal metatarsal head to the plantar shaft. A cannulated drill was used over the guide wire to create a hole for the screw. Herbert screw fixation was gradually applied (Fig. 2) and the capsular incision and skin was sutured (Fig. 3). Finally, a hallux cast was applied to the patient. The mean surgery time was $25( \pm 5)$ minutes. The mean hospitalization duration was 1 day.

From postoperative day 1 to 3 weeks, the patients were mobilized with crutches, were weight-bearing, and allowed the heel to touch in cast. The cast was removed after 3 weeks and full weight-bearing was allowed as tolerated. Patients were mobilized as tolerated without any supports at 3 to 6 weeks. Comfortable shoes were used after 6 weeks. At the 12 month follow-up, the patients were assessed using the satisfaction scale questionnaire of American Orthopedic Foot and Ankle Society (AOFAS). Questions included their pain level, existence of any deformity, and their functional, social, and professional status $(12,13)$. The AOFAS halluxmetatarsophalangeal-interphalangeal scale was also used for the patients' physical preoperative assessment. The values greater than 75 points were accepted satisfactory, and values below 75 points unsatisfactory. The mid-term results of surgery satisfaction were aimed to show that is why the AOFAS scale was applied at 12 months period.

In addition to AOFAS, the preoperative and postoperative degrees of plantarflexion and dorsiflexion of the first metatarsophalangeal joint was recorded. Anteroposterior (AP) and lateral weight-bearing $\mathrm{x}$-rays were taken to measure the correction amount and to compare postoperative bone healing with preoperative $\mathrm{x}$-rays at 6 and 12 weeks and at 12 months (Figs. 4-8). The hallux valgus angle (HVA) and intermetatarsal angle (IMA) were measured on foot AP radiographs.

The data were analyzed with the SPSS statistical software package (SPSS, Inc, Chicago, 15). A power analysis was performed to ensure that the study contained adequate number of patients. Kolmogorov-Smirnov test was used to determine the normality of data which resulted normal distribution with the same mean and standart deviation. Preoperative and postoperative results of each parameter were compared using Student's t-test and $p<0.05$ was considered to be significant. The Student's t-test for paired data showed a significant improvement in the clinical (AOFAS) and radiographic aspects with this technique.

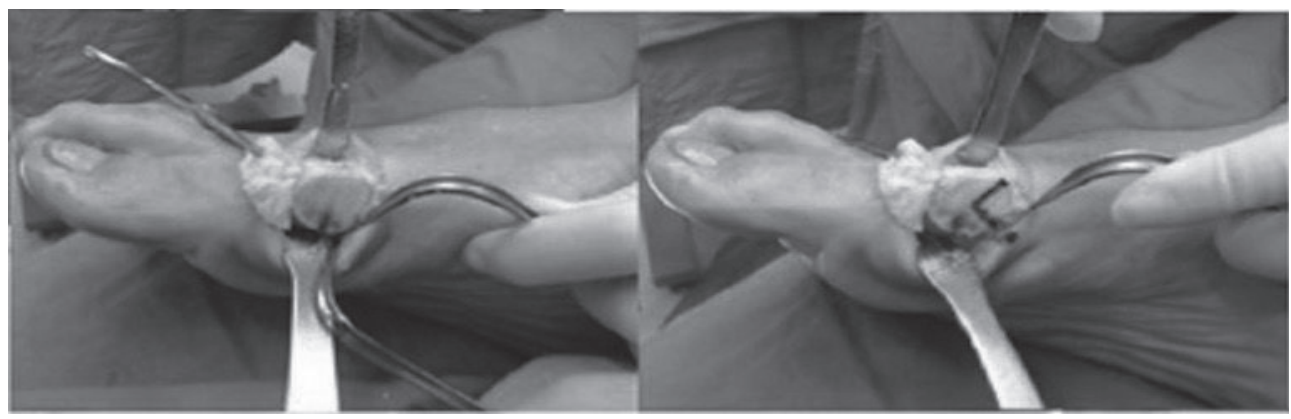

Figure 1 Bunion Excision and Chevron Osteotomy

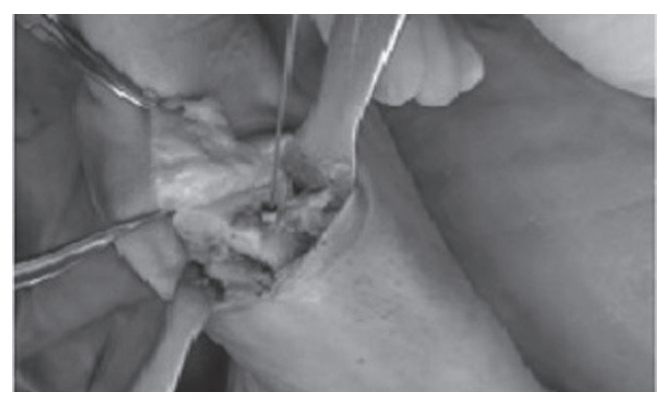

Figure 2 Herbert Screw Insertion

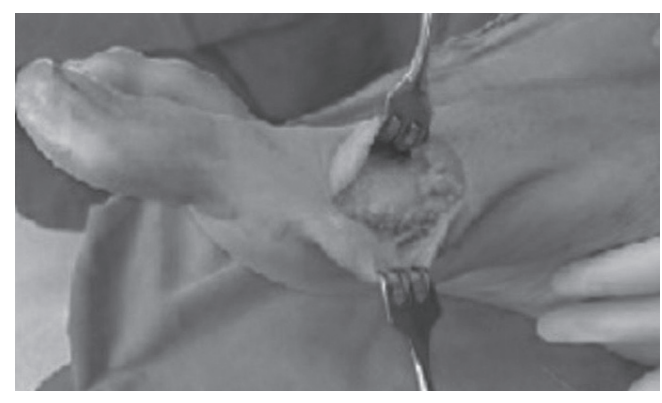

Figure 3 Capsular repair 


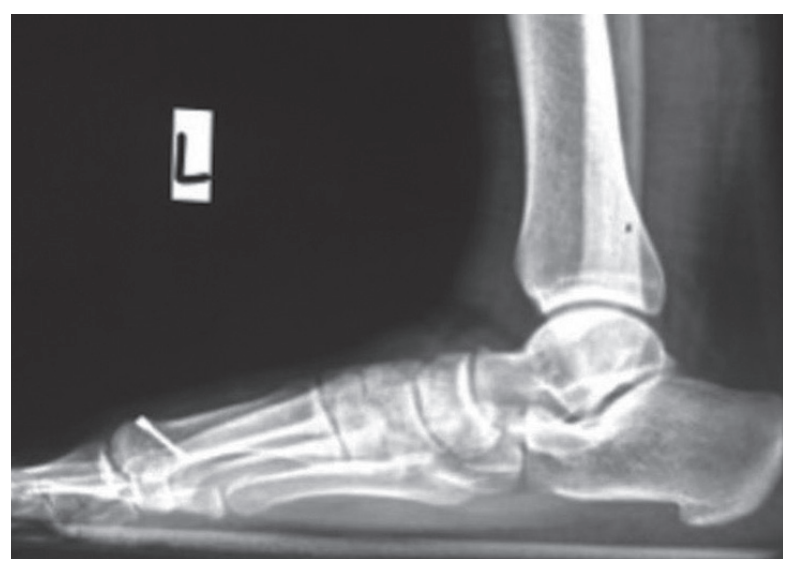

Figure 4 Radiographic View of Herbert Screw

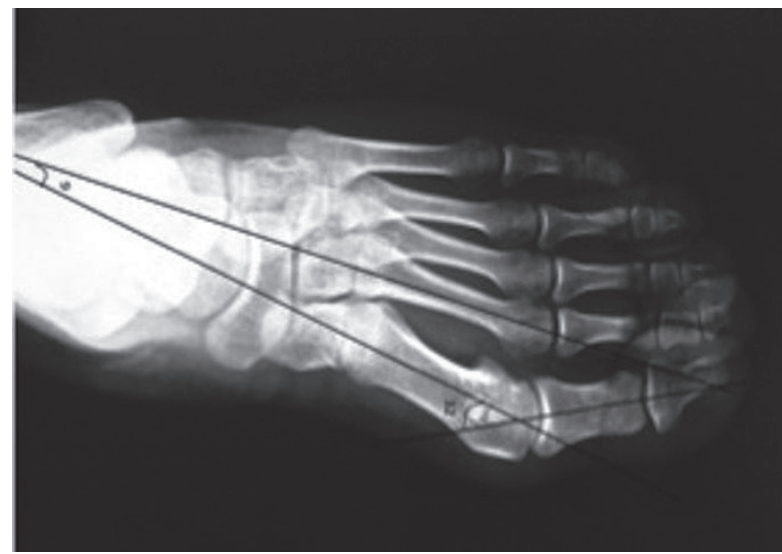

Figure 6a Preoperative X-ray Findings

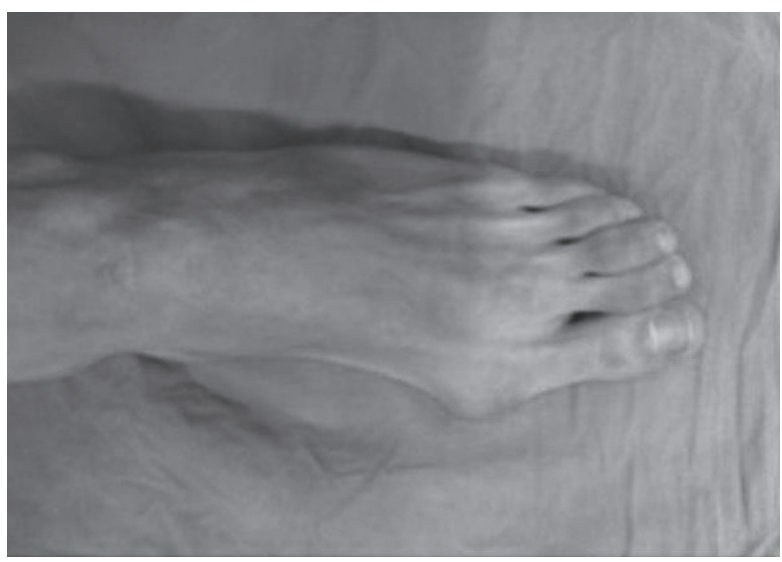

Figure 5 Preoperative Evaluation

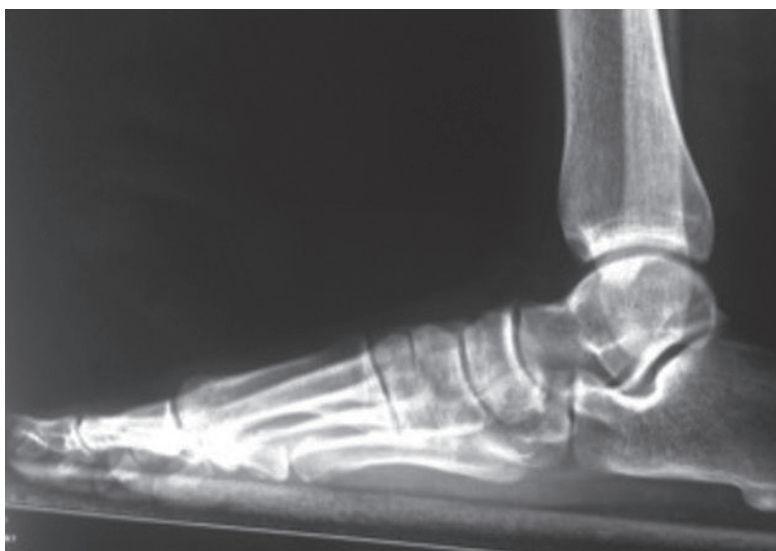

Figure 6b Preoperative X-ray Findings

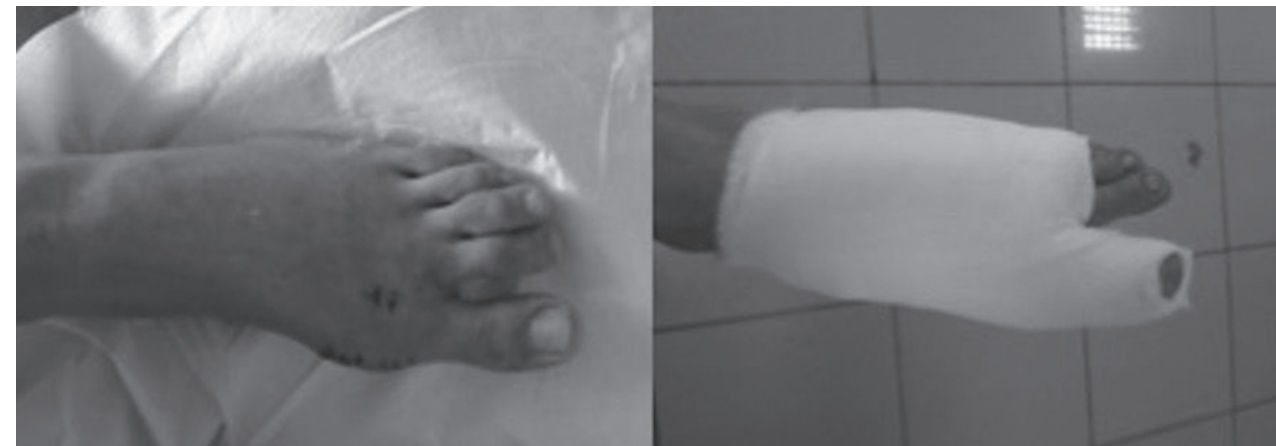

Figure 7 Postoperative Evaluation 


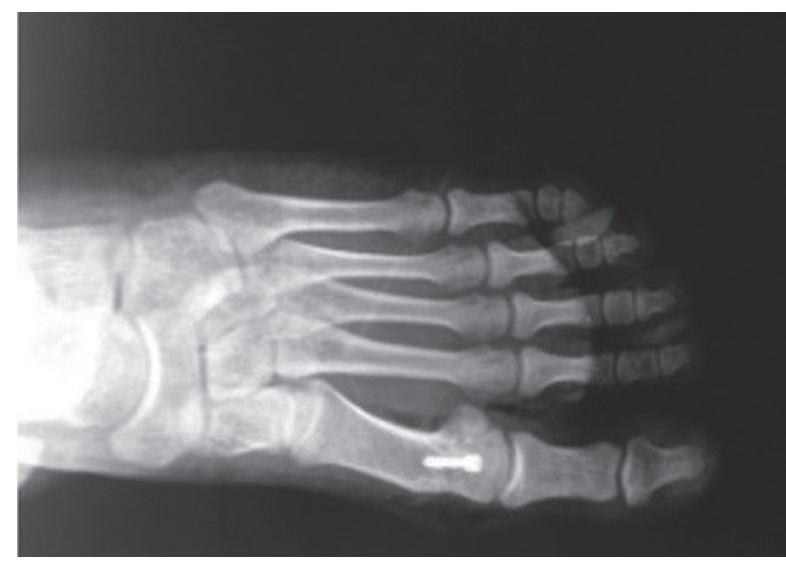

Figure 8a Postoperative X-ray Findings

\section{Results}

Clinical and radiological parameters of the patients of HVA, IMA, AOFAS score and dorsiflexion amount are summarized in Table 1. The mean follow-up time was 18 months and all patients were monitored for the duration of the study.

There was a significant decrease in the HVA from $28.93^{\circ}$ $\pm 6.66^{\circ}\left(20^{\circ}-40^{\circ}\right)$ preoperatively to $9.48^{\circ} \pm 3.21^{\circ}\left(4^{\circ}-16^{\circ}\right)$ postoperatively $(p=0.0001)$. The IMA also decreased from $11.51^{\circ} \pm 2.41^{\circ}\left(8^{\circ}-15^{\circ}\right)$ preoperatively to $7.53^{\circ} \pm 2.10^{\circ}\left(4^{\circ}-\right.$ $\left.11^{\circ}\right)$ postoperatively $(\mathrm{p}=0.001)$.

The degree of dorsiflexion of the first metatarsophalangeal joint increased from $52.48^{\circ} \pm 9.71^{\circ}\left(40^{\circ}-60^{\circ}\right)$ preoperatively to $61.90^{\circ} \pm 10.47^{\circ}\left(55^{\circ}-70^{\circ}\right)$ postoperatively $(p=0.0001)$. The plantar flexion scores significantly increased from $20.36^{\circ} \pm 4.57^{\circ}\left(15^{\circ}-30^{\circ}\right)$ preoperatively to $24.71^{\circ} \pm 5.18^{\circ}$ $\left(20^{\circ}-30^{\circ}\right)$ postoperatively $(p=0.0001)$.

Surgical treatment was associated with a significant increase in the AOFAS score from $43.77 \pm 14.14(20-75)$ preoperatively to $85.38 \pm 14.34$ (77-95) postoperatively $(p=0.0001)$. Preoperative and postoperative results are summarized in Table 2.

Postoperative presence of soft callus of the osteotomy site was observed at 3 weeks, while complete callus formation was observed at 6 weeks. All patients were returned their previous activity levels at 6 weeks. The most common complications of infection, implant irritations, hallux varus, avascular necrosis of the metatarsal head, and fracture were not observed in the patients.

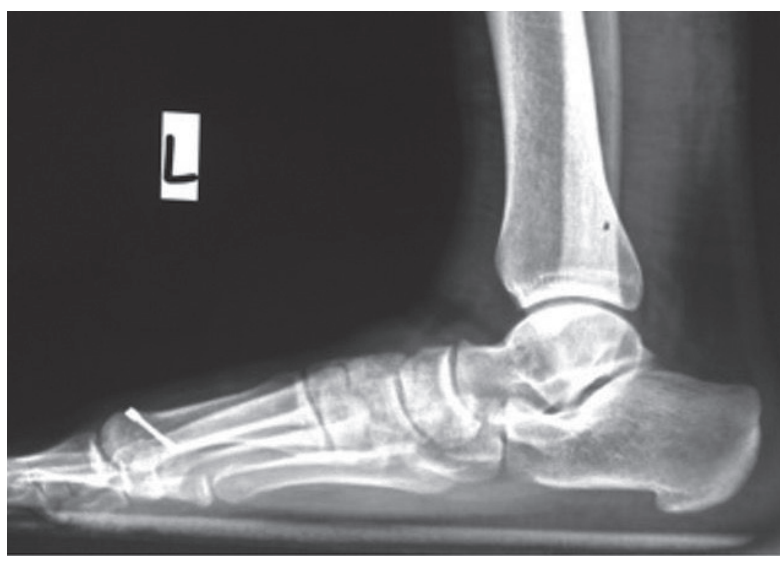

Figure 8b Postoperative X-ray Findings

\section{Discussion}

Successful chevron osteotomy for the treatment of hallux valgus requires sagittal and coronal plane stability; thus, fixation becomes a more important consideration with the chevron procedure (1-3, 6-11). Published data support chevron osteotomy both with and without fixation. Contrary to non-fixation, the majority of authors believe that fixation should be performed to improve stability and bone healing. Discussions continue as to which implant and fixation type is the most efficient $(5-9,14)$.

Non-fixation advocates suggest that implants result in higher complication rates post hallux valgus surgery and they do not recommend internal fixation. They predict that the advantage of the chevron osteotomy shape provides more translation stability than other shapes $(1,11,15)$. Ozkurt et al. (11) supported the idea that chevron osteotomy without internal fixation was enough for correction, they also added capsuloperiosteal flap shifting and fixing to the proximal fragment to provide stability, compression, and healing. Initially, Hans-JorgTrnka et al. (2) stated that they preferred cast immobilization after osteotomy with no additional fixation, until intolerable and recurrent complications led them to add pin fixation.

Caminear et al. (3) used absorbable copolymer pins for rigid fixation after chevron osteotomy that resulted in only one insignificant complication of pin site granuloma. In another study, Jacobson et al. (4) studied saw bones to demonstrate the power of different fixation techniques after hallux valgus osteotomies. They reported that a $2.7 \mathrm{~mm}$ $\mathrm{AO}$ screw fixation and $\mathrm{K}$-wire combination was the most stable and rigid construct. Singh et al. (1) reported a lower 
Table 1 Demographic and Clinical Characteristics of the Patients'

\begin{tabular}{|c|c|c|c|c|c|c|c|c|c|c|c|c|c|}
\hline & & & & $\begin{array}{r}\text { HALLUX } \\
\text { ANC }\end{array}$ & $\begin{array}{l}\text { VALGUS } \\
\text { GLE }\end{array}$ & $\begin{array}{r}\text { INTERM } \\
\text { A }\end{array}$ & $\begin{array}{l}\text { IATARSAL } \\
\text { GLE }\end{array}$ & AOP & FAS & DORSI F & LEXION & PLANTAR & FLEXION \\
\hline & Age & Foot & Gender & $\begin{array}{c}\text { Pre } \\
\text { operative }\end{array}$ & $\begin{array}{c}\text { Post } \\
\text { operative }\end{array}$ & $\begin{array}{c}\text { Pre } \\
\text { operative }\end{array}$ & $\begin{array}{c}\text { Post } \\
\text { operative }\end{array}$ & $\begin{array}{c}\text { Pre } \\
\text { operative }\end{array}$ & $\begin{array}{c}\text { Post } \\
\text { operative }\end{array}$ & $\begin{array}{c}\text { Pre } \\
\text { operative }\end{array}$ & $\begin{array}{c}\text { Post } \\
\text { operative }\end{array}$ & $\begin{array}{c}\text { Pre } \\
\text { operative }\end{array}$ & $\begin{array}{c}\text { Post } \\
\text { operative }\end{array}$ \\
\hline 1 & 24 & $\mathrm{~L}$ & $\mathrm{M}$ & 32 & 6 & 9 & 8 & 42 & 85 & 55 & 65 & 25 & 25 \\
\hline 2 & 22 & $\mathrm{~L}$ & $M$ & 30 & 8 & 9 & 9 & 47 & 90 & 50 & 55 & 20 & 25 \\
\hline 3 & 53 & $\mathrm{R}$ & $\mathrm{F}$ & 28 & 9 & 11 & 8 & 45 & 90 & 55 & 60 & 25 & 30 \\
\hline 4 & 25 & $\mathrm{R}$ & $\mathrm{M}$ & 26 & 6 & 11 & 8 & 42 & 80 & 60 & 60 & 20 & 30 \\
\hline 5 & 25 & $\mathrm{R}$ & $M$ & 29 & 4 & 8 & 4 & 32 & 90 & 60 & 70 & 20 & 20 \\
\hline 6 & 39 & $\mathrm{R}$ & $\mathrm{F}$ & 30 & 10 & 14 & 10 & 20 & 82 & 50 & 65 & 15 & 20 \\
\hline 7 & 24 & $\mathrm{R}$ & $M$ & 32 & 9 & 14 & 11 & 27 & 77 & 60 & 65 & 20 & 25 \\
\hline 8 & 27 & $\mathrm{~L}$ & $\mathrm{M}$ & 40 & 7 & 11 & 7 & 43 & 87 & 50 & 60 & 20 & 20 \\
\hline 9 & 49 & $\mathrm{~L}$ & $\mathrm{~F}$ & 32 & 11 & 11 & 9 & 42 & 90 & 50 & 65 & 20 & 25 \\
\hline 10 & 23 & $\mathrm{~L}$ & $\mathrm{M}$ & 40 & 10 & 12 & 7 & 38 & 90 & 50 & 60 & 15 & 20 \\
\hline 11 & 40 & $\mathrm{~L}$ & $\mathrm{~F}$ & 31 & 10 & 12 & 8 & 26 & 77 & 55 & 65 & 20 & 25 \\
\hline 12 & 23 & $R$ & $M$ & 32 & 12 & 11 & 9 & 48 & 93 & 60 & 65 & 20 & 20 \\
\hline 13 & 23 & $\mathrm{~L}$ & $\mathrm{M}$ & 28 & 10 & 10 & 8 & 43 & 90 & 55 & 65 & 25 & 25 \\
\hline 14 & 22 & $\mathrm{~L}$ & $M$ & 36 & 12 & 12 & 9 & 36 & 85 & 50 & 60 & 20 & 20 \\
\hline 15 & 28 & $\mathrm{~L}$ & $M$ & 34 & 14 & 13 & 10 & 42 & 87 & 40 & 60 & 15 & 20 \\
\hline 16 & 21 & $\mathrm{~L}$ & $M$ & 28 & 12 & 11 & 9 & 40 & 90 & 50 & 65 & 20 & 25 \\
\hline 17 & 21 & $\mathrm{R}$ & $M$ & 35 & 12 & 12 & 6 & 75 & 95 & 60 & 70 & 25 & 30 \\
\hline 18 & 21 & $\mathrm{R}$ & $M$ & 25 & 11 & 12 & 4 & 54 & 80 & 60 & 60 & 20 & 25 \\
\hline 19 & 21 & $\mathrm{R}$ & $\mathrm{M}$ & 30 & 7 & 15 & 6 & 68 & 85 & 55 & 65 & 20 & 30 \\
\hline 20 & 53 & $\mathrm{~L}$ & $F$ & 30 & 10 & 13 & 8 & 40 & 87 & 50 & 65 & 20 & 25 \\
\hline 21 & 24 & $\mathrm{R}$ & $\mathrm{M}$ & 23 & 12 & 11 & 9 & 54 & 82 & 55 & 65 & 25 & 25 \\
\hline 22 & 23 & $\mathrm{~L}$ & $M$ & 30 & 10 & 12 & 5 & 29 & 93 & 50 & 65 & 20 & 30 \\
\hline 23 & 24 & $R$ & $\mathrm{M}$ & 29 & 15 & 10 & 7 & 40 & 95 & 50 & 70 & 20 & 25 \\
\hline 24 & 41 & $\mathrm{~L}$ & $M$ & 40 & 12 & 13 & 9 & 37 & 87 & 40 & 60 & 15 & 25 \\
\hline 25 & 44 & $\mathrm{~L}$ & $\mathrm{~F}$ & 27 & 6 & 13 & 9 & 34 & 90 & 50 & 60 & 20 & 20 \\
\hline 26 & 28 & $\mathrm{R}$ & $\mathrm{M}$ & 21 & 10 & 10 & 6 & 48 & 90 & 60 & 65 & 20 & 25 \\
\hline 27 & 25 & $\mathrm{~L}$ & $M$ & 20 & 6 & 12 & 7 & 59 & 83 & 60 & 60 & 20 & 30 \\
\hline 28 & 24 & $\mathrm{~L}$ & $M$ & 22 & 9 & 13 & 6 & 68 & 95 & 60 & 70 & 20 & 30 \\
\hline 29 & 22 & $\mathrm{R}$ & $M$ & 25 & 6 & 15 & 8 & 47 & 90 & 60 & 60 & 20 & 25 \\
\hline 30 & 29 & $\mathrm{R}$ & $\mathrm{F}$ & 26 & 8 & 14 & 8 & 40 & 90 & 55 & 65 & 20 & 20 \\
\hline 31 & 22 & $\mathrm{~L}$ & $M$ & 34 & 16 & 13 & 11 & 52 & 82 & 55 & 60 & 25 & 30 \\
\hline 32 & 42 & $L$ & $\mathrm{~F}$ & 30 & 12 & 12 & 5 & 40 & 90 & 50 & 60 & 30 & 30 \\
\hline 33 & 23 & $\mathrm{~L}$ & $M$ & 24 & 10 & 10 & 8 & 60 & 93 & 60 & 70 & 25 & 30 \\
\hline 34 & 35 & $\mathrm{R}$ & $M$ & 26 & 6 & 12 & 6 & 52 & 90 & 55 & 65 & 20 & 30 \\
\hline
\end{tabular}

AOFAS: American Orthopedic Foot and Ankle Society

recurrence rate using a simple suture to stabilize the chevron osteotomy compared with an Austin non-fixed osteotomy. The Austin technique attributed a $10 \%$ recurrence rate as a result of inadequate soft tissue balance and fixation and is a comparable recurrence rate associated with internal fixation.
In the studies by Singh et al. $(1,16)$ a $3.3 \%$ recurrence rate with a simple suture fixation was reported. They concluded that when using a proper technique, the use of any fixation implant was also required.

In this study, the aim was to get the rotational stability with the osteotomy shape and translational stability with the 


\begin{tabular}{|c|c|c|c|}
\hline & Preoperative (SD) & $\begin{array}{l}\text { Postoperative } \\
12^{\text {th }} \text { month (SD) }\end{array}$ & $P$ value \\
\hline HVA & $28.93^{\circ} \pm 6.66$ & $9.48^{\circ} \pm 3.21$ & ${ }^{* * *} p<.0001$ \\
\hline IMA & $11.51^{\circ} \pm 2.41$ & $7.53^{\circ} \pm 2.10$ & ${ }^{* * *} p<.0001$ \\
\hline Dorsiflexion scores & $52.48^{\circ} \pm 9.71$ & $61.90^{\circ} \pm 10.47$ & ${ }^{* \star *} p<.0001$ \\
\hline Plantar flexion scores & $20.36^{\circ} \pm 4.57$ & $24.71^{\circ} \pm 5.18$ & ${ }^{* * *} p<.0001$ \\
\hline AOFAS score & $43.77 \pm 14.14$ & $85.38 \pm 14.34$ & ${ }^{\star * \star} p<.0001$ \\
\hline
\end{tabular}

Herbert screw therefore distal to proximal and dorsal to plantar Herbert screw fixation was performed to stabilize the chevron osteotomy. Over the 18 month postoperative follow-up of the patients, there were no recurrences or complications. Foreign-body reactions, implant failure, screw breakage, bone fracture due to poor vascularity, infection, or metatarsal head avascular necrosis that have been reported with other bioabsorbable implants were not encountered.

Some studies have discussed lateral capsular release and consequent osteonecrosis in the metatarsal head after non-fixation chevron osteotomies. Meier and Kenzora (17) reported a $40 \%$ prevalence of osteonecrosis of the metatarsal head when adding the lateral release. Schneider et al. (5) reported two cases of metatarsal head osteonecrosis in 112 patients who underwent chevron osteotomy and lateral release. Pochatko et al. performed lateral release during 42 hallux valgus surgeries and showed no evidence of avascular necrosis on radiographs. Furthermore, Courtman and Weighill reported a $21 \%$ osteonecrosis rate of the first metatarsal head in 38 patients, while Peterson et al. reported just one case in 42 patients (18-20). In this study, lateral release in a proper manner was performed and any osteonecrosis of the metatarsal head wasn't observed and V-shaped (reverse chevron) or modified chevron osteotomies so as not to damage the vascularity of the metatarsal head. This technique preserves the capsular blood supply. Baykal et al. (21) reported on 41 patients (49 foot surgeries) using a modified crescentic proximal osteotomy and soft tissue procedure. They reported only three minor complications and suggested that metatarsal head osteonecrosis was unlikely to occur when using the proper technique.

In hallux valgus surgery, internal fixation options vary depending on the experience of the surgeon. K-wires, screws, Stofella compression screws, and microplates can all be used for osteotomy fixation although they can irritate the skin and soft tissue and damage the sesamoid bones. Duke (6) and Winemaker (22) reported a 9\% K-wire migration of the osteotomy site and emphasized a skin irritation rate of $23 \%$ in the K-wire procedure. Quinn et al. (14) showed no skin irritations and reported an early range of motion with rigid fixation of Herbert screws in 204 foot surgeries. Yearian et al. (8) reported a $4 \%$ skin irritation rate associated with microplate and screw fixation. Further, biodegradable implants require special instrumentation and associated complications include sterile sinus formation, sterile tissue reaction, and granuloma.

From a different perspective, Park et al. (23) showed a higher recurrence of plate fixation compared with K-wire fixation following hallux valgus surgery. Mühlbauer et al. (24) suggested that K-wires fixed in surgery should be taken out 6 weeks later and is a disadvantage of the technique. Kurklu et al. (25) used Stofella pins in 73 hallux valgus surgeries and reported that early joint mobilization resulted in better functional outcomes (25).

The implant removal rate due to soft tissue irritation was reported to be low due to the unique head design of the 
Herbert screw. Windhagen et al. (26) reported that an advantage of biodegradable screws was that they do not need to be removed (26). In this study the Herbert screw was burried into the bone so that skin and soft tissue irritations did not occur. Intraoperative fluoroscopic images allowed to identify the appropriate screw size to avoid any damage to sesamoid bones (Fig. 4) and eliminated the necessity for implant removal.

Some surgeons preferred to use hallux casting for 6 weeks postoperatively. However, the majority considered that casting longer than 3 weeks led to stiffness in the metatarsophalangeal joint. Rossi and Johnson (15) reported a $4.8 \%$ to $42 \%$ joint stiffness rate. In addition, Rossi et al. (27) reported that a cast application of 2-3 weeks reduced reduction loss. However, long-term casting causes metatarsophalangeal joint stiffness; therefore, casting was applied for only 3 weeks.

Klosok et al. (28) reported that the mean time of return to work was 7 weeks, which is compatible with our data. The soft callus formation was demonstrated by $x$-ray at 3 weeks and osteotomy site union between 3 to 6 weeks, so the return to work was scheduled for 6 weeks postoperatively. In conclusion, rapid postoperative healing and good surgical outcomes with an ease of application could be stated the advantages of the Chevron osteotomy with Herbert screw fixation in hallux valgus surgery. As the Herbert screw was buried into the bone, the necessity for implant removal was eliminated. It is easy to perform with no need for incision extension, thus reducing postoperative complications with quick return to previous activity levels.

Acknowledgements: I would like to thank for Dr.Zafer Atbaş for his contribution in collecting data and statistical analysis. Conflict of interest: None

Finance: None

\section{References}

1. Singh SK, Jayasekera N, Nazir S, Sharif K, Kashif F. Use of a simple suture to stabilize the chevron osteotomy: a prospective study. J Foot Ankle Surg. 2004; 43 (5):307311 .

2. Trnka HJ, Zembsch A, Easley ME, Salzer M. The Chevron osteotomy for correction of hallux valgus: Comparison of findings after two and five years of follow-up. Bone Joint Surg Am. 2000; 82 A(10):1373-1378, .

3. Caminear DS, Pavlovich R Jr, Pietrzak WS. Fixation of the chevron osteotomy with an absorbable copolymer pin for treatment of hallux valgus deformity. J Foot Ankle Surg. 2005; 44 (3):203-210.
4. Jacobson K, Gough A, Mendicino SS, Rockett MS. Mechanical comparison of fixation techniques for the offset V osteotomy: a saw bone study. J Foot Ankle Surg. 2003; $42(6): 339-43$,

5. Schneider W, Aigner N, Pinggera O, Knahr K. Chevron osteotomy in hallux valgus: ten-year results of 112 cases. $J$ Bone Joint Surg Br. 2004; 86 (7):1016-1020, .

6. Winemaker MJ, Amendola A. Comparison of bioabsorbable pins and Kirschner wires in the fixation of Chevron osteotomies for hallux valgus. Foot Ankle Int. 1996; 17 (10):623-628.

7. Hanft JR, Kashuk KB, Bonner AC, Toney M, Schabler J. Rigid internal fixation of the Austin/chevron osteotomy with Herbert screw fixation: a retrospective study. J Foot Surg.1992; 31 (5):512-518.

8. Yearian PR, Brown T, Goldman F. Chevron bunionectomy with mi- croplate and screw fixation: a retrospective followup of 26 feet. J Foot Ankle Surg. 1996; 35 (6):532-536.

9. Small HN, Braly WG, Tullos HS. Fixation of the Chevron osteotomy utilizing absorbable polydioxanon pins. Foot Ankle Int.1995; 16 (6):346-350.

10. Barca F, Busa RA. Chevron osteotomy fixed with bioabsorbable poly-L-lactic acid single screw. J Foot Ankle Surg. 1997; 36 (1):15-20.

11. Ozkurt B, Altay M, Aktekin CN, Toprak A, Tabak Y. Capsuloperiosteal flap application for the stabilization of chevron osteotomy. Acta Orthop Traumatol Turc. 2006; 40 (2):151-157.

12. Kitaoka HB, Alexander IJ, Adelaar RS, Nunley JA, Myerson MS, Sanders M. Clinical rating systems for the ankle-hindfoot, midfoot, hallux, and lesser toes. Foot Ankle Int. 1994; 15 (7):349-53.

13. Ibrahim T, Beiri A, Azzabi M, Best AJ, Taylor GJ, Menon DK. Reliability and validity of the subjective component of the American Orthopedic Foot and Ankle

Society clinical rating scales. J Foot Ankle Surg. 2007; 46 (2):65-74.

14. Quinn MR, DiStazio JJ, Kruljac SJ. Herbert bone screw fixation of the Austin bunionectomy. J Foot Surg. 1987; 26 (6):516-519.

15.Johnson JE, Clanton TO, Baxter DE, Gottlieb MS. Comparison of Chevron osteotomy and modified McBride bunionectomy for correction of mild to moderate hallux valgus deformity. Foot Ankle Int. 199112 (2):61-68.

16. Austin DW, Leventen EO. A new osteotomy for hallux valgus: a horizontally directed "V" displacement osteotomy of the metetarsal head for hallux valgus and primus varus. Clin Orthop Jun. 1981; 157:25-30.

17. Meier PJ, Kenzora JE. The risks and benefits of distal first metatarsal osteotomies. Foot Ankle Int. 1985; 6 (1):7-17. 18. Pochatko DJ, Schlehr FJ, Murphey MD, Hamilton JJ. Distal chevron osteotomy with lateral release for treatment 
of hallux valgus deformity. Foot Ankle Int. 1994; 15 (9):457-

461.

19. Courtman NH, Weighill FJ. Distal first metatarsal osteotomy and adductor release as a treatment of hallux valgus. J R Coll Surg Edinb. 1995; 40 (2):133-5.

20. Peterson DA, Zilberfarb JL, Greene MA, Colgrove RC. Avascular necrosis of the first metatarsal head: incidence in distal osteotomy combined with lateral soft tissue release. Foot Ankle Int Feb 15;(2):59-63, 1994.

21. Baykal B, Kirdemir V, Ateşalp AS, Bek D, Tercan V. Modified crescentic proximal metatarsal osteotomy and distal soft tissue procedures in hallux valgus. Mil Med Dec.2006; 171 (12):1247-1250, .

22. Duke HF. Buried Kirschner wire fixation of the Austin osteotomy-bunionectomy: a preliminary report. J Foot Surg. 1986; 25 (3):197-203.

23. Park $\mathrm{CH}$, Ahn JY, Kim YM, Lee WC. Plate fixation for proximal chevron osteotomy has greater risk for hallux valgus recurrence than Kirschner wire fixation. Int Orthop. 2013; 37 (6):1085-1092.

24. Mühlbauer M, Zembsch A, Trnka HJ. Short-term results of modified chevron osteotomy with soft tissue technique and guide wire fixation: a prospective study. Z Orthop Ihre Grenzgeb. 2001; 139 (5):435-9.

25. Kürklü M, Demiralp B, Yurttaş Y, Ciçek El, Ateşalp AS. Modified chevron osteotomy fixed with stofella pin for hallux valgus. Foot Ankle Int. 2008; 29 (5):478-82.

26. Windhagen $H$, Radtke $K$, Weizbauer A, Diekmann J, Noll Y, Kreimeyer U, Schavan R, Stukenborg-Colsman C, Waizy H. Biodegradable magnesium-based screw clinically equivalent to titanium screw in hallux valgus surgery: short term results of the first prospective, randomized, controlled clinical pilot study. Biomed Eng Online 2013; 12:62-72.

27. Rossi WR, Ferreira JC. Chevron osteotomy for hallux valgus. Foot Ankle. 1992; 13 (7):378-81.

28. Klosok JK, Pring DJ, Jessop JH, Maffulli N. Chevron or Wilson metatarsal osteotomy for hallux valgus. A prospective randomized trial. J Bone Joint Surg. 1993; 75 (5):825-829. 